\title{
Eke, ásó, kapa és nagyharang, avagy tanulmány a nemi szerepek eredetéról ${ }^{1}$
}

\author{
JUHÁSZNÉ FAZEKAS ZSUZSANNA²
}

Számtalan tanulmány született már a férfi és a női szerepek különbözőségeiről, a nemek közötti egyenlőtlen viszonyokról, és egyáltalán mindarról, ami a férfi és nő közötti társadalmi, biológiai különbséget jelenti, jelentheti. Az általam bemutatni kívánt tanulmány a nemi szerepek eredetét állítja a középpontba. Az elemzés unikális jellegét az adja, hogy annak ellenére, hogy közgazdászok írták, azok számára is fogyasztható, akik hadilábon állnak a gazdasági és matematikai mutatók és összefüggések értelmezésével.

A tanulmány fókuszában a nők társadalmi szerepvállalása, valamint a vizsgált közösségekre jellemző kulturális hiedelmek, normák és szokások munkamegosztást befolyásoló tényezőinek vizsgálata áll. A kutatók azt feltételezték, hogy a nemi szerepek alakulását jelentősen befolyásolta a tradicionális mezőgazdaság technológiája, és az ebből fakadó férfi-női munkamegosztás jellemző tényezői.

A kutatók úgy vélték, hogy azok a társadalmak, ahol az emberek ekével művelték a földjeiket, amelyben a nőknek kevesebb szerep jutott, ott a nők ma is kevésbé jelennek meg a munkaerőpiacon, a vállalkozói szektorban és a politikában, vagyis a valamikori technológia alapú „természetes” egyenlőtlenség máig fennmaradt.

A vizsgálat kiinduló fázisa a valamikori társadalmak mezőgazdasági rendszereinek elemzése. Ehhez figyelembe veszik azok földrajzi, geológiai, éghajlati adottságait és etnikai összetételüket. Számos adatbázist használtak fel a kutatás során (pl. Ethnographic Atlas, Global Agro-Ecological Zones, Ethnologue: Languages of the World, Landscan), és bonyolult matematikai számítások alkalmazásával kerestek összefüggéseket a korabeli társadalmak etnikai, földrajzi, történelmi, nyelvi és gazdasági jellemzői, s ezek nemi szerepekre gyakorolt hatása között.

Az ősi gazdasági rendben megteremtődött, de a hagyományok által máig átörökített nemi szerepeket az USA-ban élő második generációs bevándorló nők munkaerőpiaci jellemzőinek feltérképezése segítségével vizsgálták. Hipotézisük az volt, hogy a

${ }^{1}$ Alesina, A. F. - Giuliano, P. - Nunn, N. (2011). On the Origins of Gender Roles: Women and the Plough (No. w17098). National Bureau of Economic Research. DOI: 10.3386/w17098

${ }^{2}$ Debreceni Egyetem Humán Tudományok Doktori Iskola Szociológia és Társadalompolitika Doktori Program, e-mail: fazekzsu@gmail.com. 


\section{OLVASS FELESLEGESET!}

migránsok származási helyének hagyományos nemi szerepei továbbra is megjelennek a munkaerőpiaci viselkedésben. Másként, hogy a migránsok magukkal hozott értékrendjének tehetetlenségi ereje nagy, s noha az útravalónak szánt „hamuba sült pogácsa" elfogyhat, annak íze örökre végigkísér bennünket.

Az elemzés első lépéseként egy 2000-ben végzett munkaerőpiaci felmérés eredményeit használták fel, amelyben a nők részvételét vizsgálták ${ }^{3}$, és igen markáns különbségeket találtak: például Pakisztánban a nők 16,1\%-a, a kelet-afrikai Burundiban pedig a nők 90,5\%-a található meg a munkaerőpiacon. A különbségeknek számtalan okát tárták fel a kutatások, többek között az adott ország gazdaságszerkezetét, azoknak az iparágaknak a hiányát, amelyek többnyire a nőknek kedveznek.

Ám azt feltételezték, hogy ezeknek az eltéréseknek mélyebb, a történetbe ágyazott okai is lehetnek. Boserup (1970) kutatásaira alapoztak, aki szerint a nemi szerepek különbözőségei a hagyományos mezőgazdasági gyakorlatból erednek, a nemi szerepek különbözőségének eredetvizsgálatához pedig a tradicionális mezőgazdasági gyakorlatok kialakulásához kell visszatekintenünk. Boserup azt mondja, hogy az egyszerű eszközökkel végzett (ásó, kapa) mezőgazdasági munka és az ekével végzett tevékenységek egyenlőtlenségekhez vezettek a férfiak és nők közötti munkamegosztás terén, ami mögött a termesztett növények milyensége húzódhatott meg (pl. könnyű vagy nehéz munka egy nő számára növényeket termeszteni, melyik növény termesztésére mennyi munkát kell fordítani). Úgy vélte, hogy az eke használatának történelmi szerepe volt abban, hogy a későbbi nemi szerepek hogyan alakultak: míg a kézi szerszámok használatát igénylő mezőgazdasági feladatokban a nők nagy szerepet tudtak vállalni, addig az ekére való áttérés a nagyobb fizikai erőkifejtés miatt (az ekét fogni, az ekét a barázdában tartani, a befogott állatot irányítani) felértékelte a férfiak munkáját.

Mivel ez a munkaforma már nem igényelte a nők és a gyerekek munkáját (pl. gyomlálás) a földeken, olyan intenzitással, mint korábban, ezért a nőknek olyan munkákat kellett elvégezniük, amit a gyermek nevelése és gondozása miatt félbeszakíthattak. Gondoljunk csak bele, mennyivel könnyebb letenni a kapát akkor, ha meg kell etetni a gyermeket, mint az ekét vonó állatot megállítani? A nők tehát az otthoni és ház körüli munkák felé fordultak, mert a gyermekek gondozása és nevelése mellett ezek sokkal kivitelezhetőbbek voltak. Ez a fajta munkamegosztás aztán normaként épült be a társadalmakba, és határozta meg a nők későbbi szerepét.

A nemi egyenlőtlenségek keletkezésének megértéséhez más tényezőket is figyelembe kellett venni. Így Pryor (1985) kutatását, aki szerint az ekehasználat előnye attól is függ, hogy az adott terület milyen növények megtermelésének kedvezett. Ahol például nagy fölterületeket kell rövid idő alatt megművelni, ott mindenképpen kedvező az eke használatának hatása, még akkor is, ha a földterület sekély, mere-

\footnotetext{
${ }^{3}$ Az adatokat a Világbank 'World Developement Indicators' adatbázisából emelték át a kutatók.
} 


\section{OLVASS FELESLEGESET!}

dek vagy éppen sziklás. Ezek a kondíciók a búza, árpa, rozs, rizs termesztéséhez a legoptimálisabbak. Ezzel szemben a kukorica, a cirok, egyéb gumós-fás növények termesztése kisebb földterületen is lehetséges, és ott is, ahol a talaj minősége kevésbé kedvező és az eke használata bonyolult és nehézkes lenne. Ebből az következik, hogy az eke használatának bevezetését és alkalmazását a mezőgazdasági munkában az is meghatározta, hogy milyen volt az a földterület, amelyet megművelni akartak, milyen növényeket lehetett termeszteni rajta, illetve alkalmas volt-e egyáltalán az eke használatára.

De megemlítik Braudel (1998) magyarázatát is arról, hogy a nemek közötti kapcsolatokra, a kultúrára, a társadalomra milyen hatást gyakorolt az eke megjelenése. Eszerint az ősi mezopotámiai kultúrában a nőknek kiemelt szerepe volt a mezőgazdaságban, a földeken, a növények termesztésében, míg a férfiak vadásztak, az állatokkal foglalkoztak. Ám miután elkezdték a földjeiket ekével művelni a matriarchális társadalom szép lassan patriarchálissá vált, ahol a férfiak szerepe és dominanciája megkérdőjelezhetetlenné vált.

Utalnak továbbá Engels (1902) érvelésére, hogy az egyenlőtlenségek akkor keletkeztek, amikor a mezőgazdaság szerepe megerősödött a gazdaságban; kialakult a magántulajdon, amely monopolizálta a férfiak helyzetét. Ez a kiváltságos helyzet lehetőséget teremtett a férfiaknak arra, hogy a nőket alávetett szerepbe helyezzék, és az apa kizárólagos szerepét helyezzék előtérbe a gyermekek nevelése során is. Ezáltal függő helyzetbe hozva a nőt a férfitől, akik így nem voltak képesek aktív és egyenlő jogokkal felruházott résztvevőjének lenni a társadalomnak.

Végül megemlítik Whyte (1978) művét, mely szerint a háborúk is erősítették a nemek közötti egyenlőtlenségeket, hiszen a háború a férfiak dolga, és a nőket alávetett helyzetbe hozza.

Az USA-ba emigrált második generációs nők munkaerőpiaci jellemzőinek elemzése során a kutatók arra voltak kíváncsiak, hogy az átörökített kulturális normák milyen hatást gyakorolnak a nők munkavállalására. Fontos eleme a kutatási dizájnnak az, hogy a vizsgált alanyok eltérő kulturális háttere azáltal válik jól elemezhetővé, hogy a vizsgálat idején valamennyien az USA-ban éltek, s ezért az őket érő piaci folyamatok, intézmények, politika hatásai azonosak. A kérdés tehát az, hogy azoknak a nőknek, akiknek őseik ekét használtak a mezőgazdasági tevékenység során; kevésbé valószínű-e a részvétele a mai USA-beli munkaerőpiacon, mint az átlagnak. Az adatbázis, amelyet elemeztek, 1994 óta gyűjt adatokat a migránsok anyaországáról, illetve a szüleik születési országáról. ${ }^{4}$

A kutatókat az is érdekelte, hogy a kultúra átörökítésében erősebb szerepe van-e az apának. Ehhez meg kellett különböztetniük az apáról és az anyáról a lányra ható folyamatokat, vagy mindkét vonal dominálhat.

${ }^{4}$ Current Population Survey (CPS) adatbázisa a migránsok anyaországáról, illetve szüleik születési országáról, mely adatbázis 1994 óta tartalmaz adatokat. 


\section{OLVASS FELESLEGESET!}

Eredményeik szerint a házas nők munkaerőpiaci részvételét nagyban meghatározza a férj értékrendje. Összefüggést találtak a férj őseinek hagyatéka és a feleség munkaerőpiaci részvétele között.

Amikor a házas nőket vizsgálták, azt is szerették volna tudni, hogy az ekehasználat fontossága a férj származása kapcsán is számottevő-e. Így a férj őseit is vizsgálni kezdték. A kutatók azt is mérlegelték, hogy a házas nő munkaerőpiaci részvételét mennyiben befolyásolja a férj hiedelme, értékrendszere, melyet a szüleitől kapott örökül.

Bizonyítást nyert, hogy a kultúra átörökítése - már ami a gendert illeti - sokkal inkább erősebb az anyai ágról, mint az apai ág felől, akár a feleség édesanyjáról a feleségre ható örökséget, akár a férj édesanyjának férjre ható hagyományait vesszük alapul.

A kutatás azt is bizonyította, hogy az eke használatának hatása és az ebből kifolyólag áthagyományozott értékek és hiedelmek a férj szüleinél markánsabban megnyilatkoznak, mint a feleség szülei esetében.

Tehát elmondhatjuk, hogy a férj kulturális hagyatéka, hagyományai, hite és értékrendje sokkal inkább meghatározóbbak, mint a nő értékrendje; és ez egy konstans helyzet, amelynek hatása van a feleség munkaerőpiaci helyzetére is.

\section{Összegzés}

A kulturális antropológusok szerint a nemi szerepek alakulását meghatározza az, hogy a társadalmak a mezőgazdaságban az egyszerű szerszámok használatáról áttértek az eke használatára. Ez a tény a férfi és női különbözőségeket normaként ágyazta be a társadalom működésébe.

A kutatók az etnográfiai adatokat felhasználva elemzéseket készítettek az eke használatának későbbi, társadalomra és közösségekre, valamint a női munkavállalás szerepére gyakorolt hatásairól. Összefüggéseket kerestek a nemi szerepek és a régi mezőgazdasági tradíciók között. Bebizonyították, hogy azok az egyének, társadalmi csoportok, országok, ahol az ősök ekét használtak a mezőgazdaságban, nagyobb egyenlőtlenségeket mutatnak napjainkban is, és kisebb a nők részvétele a háztartáson kívüli munkavégzésben és a politikában.

Tehát, hölgyeim: a baj az, hogy nem bírtuk el az ekét. Tényleg így kezdődött?

\section{Irodalom}

Alesina, A. F. - Giuliano, P. - Nunn, N. (2011): On the Origins of Gender Roles: Women and the Plough (No. w17098). National Bureau of Economic Research. DOI: 10.3386/w17098 
www. metszetek.unideb.hu

\section{OLVASS FELESLEGESET!}

Braudel, F. (1998): Mediterranean in the Ancient World. London, Allen Lane

Boserup, E. (1970): Woman's Role in Economic Developement. London, George Allen and Unwin Ltd.

Engels, F. (1902): The Origin of the Family, Private Property and the State. Chicago, Charles A. Kerr \& Company Cooperative

Pryor, F. (1985): The Invention of the Plow. Comparative Studies in Society and History, 27(4): 727-743.

Whyte, M. K. (1978): The Status of Women in Pre-Industrial Societies. Princeton, N.J., Princeton University Press 